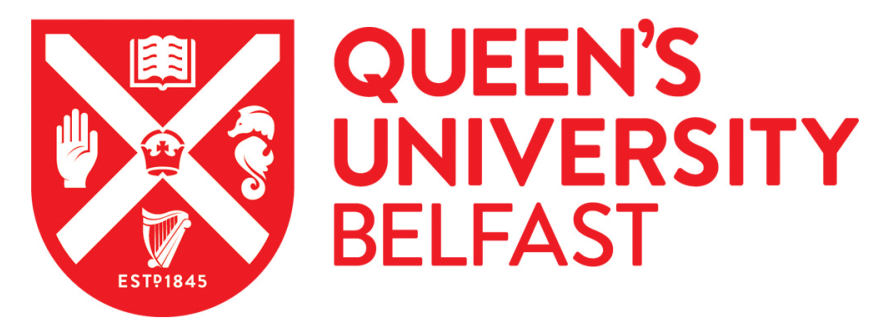

\title{
Assessment of the impact speed and angle conditions for the EN1317 barrier tests
}

Abraham, N., Ghosh, B., Simms, C., Thomson, R., \& Amato, G. (2016). Assessment of the impact speed and angle conditions for the EN1317 barrier tests. International Journal of Crashworthiness, 21(3), 211.

https://doi.org/10.1080/13588265.2016.1164444

Published in:

International Journal of Crashworthiness

Document Version:

Peer reviewed version

Queen's University Belfast - Research Portal:

Link to publication record in Queen's University Belfast Research Portal

Publisher rights

Copyright 2016 Taylor and Francis

This is an Accepted Manuscript of an article published by Taylor \& Francis in ernational Journal of Crashworthiness on 23 March 2016 , available online: $\mathrm{http}: / /$ www.tandfonline.com/doi/full/10.1080/13588265.2016.1164444

\section{General rights}

Copyright for the publications made accessible via the Queen's University Belfast Research Portal is retained by the author(s) and / or other copyright owners and it is a condition of accessing these publications that users recognise and abide by the legal requirements associated with these rights.

Take down policy

The Research Portal is Queen's institutional repository that provides access to Queen's research output. Every effort has been made to ensure that content in the Research Portal does not infringe any person's rights, or applicable UK laws. If you discover content in the Research Portal that you believe breaches copyright or violates any law, please contact openaccess@qub.ac.uk. 


\section{Assessment of the impact speed and angle conditions for the EN1317 barrier tests}

Nikil Abraham,

Mechanical Engineering Department, Trinity College Dublin, Dublin, Ireland Parsons Building. Trinity College Dublin, Dublin 2, Ireland

Bidisha Ghosh,

Civil Structural \& Environ Engineering Department, Trinity College Dublin, Dublin, Ireland Museum Building, Trinity College, Dublin 2, Ireland

Ciaran Simms

Mechanical Engineering Department, Trinity College Dublin, Dublin, Ireland Parsons Building. Trinity College Dublin, Dublin 2, Ireland

Robert Thomson

Chalmers University of Technology - Se-41296 Gothenburg, Sweden

Giuseppina Amato

School of Planning, Architecture and Civil Engineering (SPACE), Queen's University Belfast. David Keir Building, Stranmillis Road Belfast BT9 5AG, United Kingdom

\section{Keywords:}

Single Vehicle Accidents, Run-Off-Road crashes, Concrete barrier, LS-DYNA, EN1317, MASH. 


\section{Assessment of the impact speed and angle conditions for the EN1317 barrier tests}

Roadside safety barriers designs are tested with passenger cars in Europe using standard EN1317 in which the impact angle for normal, high and very high containment level tests is $20^{\circ}$. In comparison to EN1317, the US standard MASH has higher impact angles for cars and pickups $\left(25^{\circ}\right)$ and different vehicle masses. Studies in Europe (RISER) and the US have shown values for the 90th percentile impact angle of $30-34^{\circ}$. Thus the limited evidence available suggests that the $20^{\circ}$ angle applied in EN 1317 may be too low.

The first goal of this paper is to use the US NCHRP database (Project NCHRP 17-22) to assess the distribution of impact angle and collision speed in recent ROR accidents. Secondly, based on the findings of the statistical analysis and on analysis of impact angles and speeds in the literature, an LS-DYNA Finite Element analysis was carried out to evaluate the normal containment level of concrete barriers in non-standard collisions. The FE model was validated against a crash test of a portable concrete barrier carried out at the UK Transport Research Laboratory (TRL).

The accident data analysis for run-off road accidents indicates that a substantial proportion of accidents have an impact angle in excess of $20^{\circ}$. The baseline LSDYNA model showed good comparison with experimental Acceleration Severity Index (ASI) data and the parametric analysis indicates a very significant influence of impact angle on ASI. Accordingly, a review of European run-off road accidents and the configuration of EN 1317 should be performed.

Keywords: crash test; safety barriers; finite element; accident data

\section{Introduction}

Roadside safety barriers are designed to shield errant vehicles from impacts with fixed objects and other hazards in the clear zone. In $2004,45 \%$ of all EU road fatalities resulted from Single Vehicle Run-Off-Road (SVROR) accidents and 15\% of all Single Vehicle (SV) accidents involved a barrier ${ }^{(22)}$. Austrian statistics for 2002-2009 show that $45 \%$ of all crashes on motorways were SV accidents, causing $50 \%$ of fatal and severe injuries, with over $80 \%$ of total lane departures being from the nearside ${ }^{(24)}$. There are 
similar findings for Belgium, the Netherlands and the US ${ }^{(9,14,25)}$. SV accidents are thus a significant traffic safety problem and roadside barriers are an important safety countermeasure. However, exit angle and speed are two critical parameters for RunOff-Road (ROR) collisions that influence the design and implementation criteria for barriers, and exit angle and speed depend on road type, road geometry, weather and road surface conditions, vehicle position on the carriageway and left or right side road departure. A study conducted by the RISER consortium ${ }^{(18,22)}$ on 82 accidents in seven European countries showed that $90 \%$ of crashes were below $120 \mathrm{~km} / \mathrm{h}$ and $80 \%$ below $110 \mathrm{~km} / \mathrm{h}$. In a large majority (90\%) of the collisions the exit angle was below $20^{\circ}$. However, accidents from all types of roads and speed limits were included and the sample size was small ${ }^{(18)}$, see Table 1.

A study by Mak et al ${ }^{(6,13)}$ sponsored by the US Federal Highway Administration showed that $90 \%$ of the collision impact speeds were below $95 \mathrm{~km} / \mathrm{h}$ and $90 \%$ of impact angles were below $32^{\circ}$, see Table 1. However, the crash data was collected in the late $1970 \mathrm{~s}$ when there was a national speed limit of $90 \mathrm{~km} / \mathrm{h}(55 \mathrm{mph})$ and this was prior to the advent of anti-lock braking (2), which likely influences the impact angle and speed.

$\underline{\text { In } 2001 \text { Albuquerque et al (2) showed, in a study funded by the National }}$ Cooperative Highway Research Program (NCHRP) on 608 collisions which occurred between $1997-2001$ on roads with speed limits of $80-120 \mathrm{~km} / \mathrm{h}$, that the $90^{\text {th }}$ percentile impact speed was $92-106 \mathrm{~km} / \mathrm{h}$. For the same sample the corresponding $90^{\text {th }}$ percentile impact angle was $30-34^{\circ}$, see Table 1. Thus the limited evidence available suggests that the $20^{\circ}$ angle applied in EN 1317 may be too low. Therefore, in the absence of suitable European data, the first goal of this paper is to use the US NCHRP database (Project NCHRP 17-22) to assess the distribution of impact angle and collision speed in recent ROR accidents. 
New barrier designs are tested in Europe using standard EN1317 while in US the AASHTO Manual for Assessing Safety Hardware (MASH) ${ }^{(1)}$ is used, having superseded the NCHRP Report $350{ }^{(23)}$ in 2011. The required crash test for EN 1317 $(7,8)$ is related to the containment level required by the road on which the barrier is placed, see Table 2 and Table 3.

Apart from the low angle containment barrier (used only for temporary road works), the impact angle for passenger cars in normal, high and very high containment level tests is $20^{\circ}$ (except for TB41). While the choice of the $20^{\circ}$ impact angle is presumably intended to be representative of actual SVROR collisions, there are not many studies giving evidence of the actual ROR angle distribution, and none relate to European data. Moreover, since SVROR accidents account for only about half of the total rural road accidents, barrier impact angles for non-SVROR crashes may have a very different distribution.

A comparison of EN1317 with the MASH test matrix, see Table 4, shows 1) different reference vehicle mass (1100 kg car and $2270 \mathrm{~kg}$ pickup in MASH, $900 \mathrm{~kg}$ and $1500 \mathrm{~kg}$ cars in EN1317) and also 2) higher impact angles for cars and pickups and higher impact speed for HGVs in MASH. The vehicle mass difference reflects fleet differences between Europe and the US, and the US barrier angle increase from $20^{\circ}$ to $25^{\circ}$ may reflect a philosophy that the more severe impact associated with higher impact angles will result in overall safer barrier designs.

The EN1317 standard aims at improving road user safety, while at the same time being achievable by appropriate current products. However, its effectiveness depends on the ability of a single scenario to represent a range of real accidents, and a specific barrier performance in conditions different to the test is generally unknown. The recent SAVeRS project ${ }^{(9)}$ showed that, while there is a single standard across the EU, the choice of the containment level for a specific road type varies widely. Moreover, it appears that neither the criteria used to define the European Standard for barrier crash tests (EN1317) nor the accident statistics used to substantiate them have 
been published. Thus, given the recent US standard update, the context suggests that a review of the European EN 1317 is appropriate.

There is insufficient accident data to assess the performance of individual barrier designs for varying collision speed and impact angle and computational models provide a possible alternative approach for this. Accordingly, the Finite Element (FE) formulation has been used to study crashworthiness characteristics of safety barriers ${ }^{(3-}$ 5,10,15,26). In particular Atahan (3) and Marzougui (15) used LS-DYNA as a design and assessment tool for Portable Concrete Barrier and Ferdous ${ }^{(10)}$ and Borovinsek ${ }^{(5)}$ assessed the performance of steel w-beam roadside and median barriers.

Montella et al ${ }^{(17)}$ studied the effect of varying impact speed and angle on the Acceleration Severity Impact (ASI) of a concrete barrier. However, they did not assess the validity of their model and they used a rigid wall to simulate a road side barrier, thus overlooking the significant effect of the barrier displacement on the vehicle acceleration.

The second goal of this paper is thus to develop a finite element model of a vehicle and barrier system that is suitable for studying the general influence of vehicle impact speed and impact angle on the predicted Acceleration Severity Index. The findings from the modelling together with the statistical analysis of real world crashes are then used to assess the appropriateness of the test conditions in the EN 1317 standard.

This paper is composed of two parts. First, a statistical analysis is carried out on a set of SVROR collisions reported in the NCHRP database to assess the most frequent impact angles and speeds of ROR accidents. Secondly, based on the findings of the statistical analysis and on analysis of impact angles and speed in the literature, an LS-DYNA Finite Element analysis was carried out to evaluate normal containment level concrete barriers in non-standard collisions. 


\section{Methods}

\subsection{Statistical analysis of accident data}

The NCHRP data for SVROR accidents for the years 1997-2004 was extracted for statistical analysis. In the database roads are classified as "Interstate roads", US routes", "State roads" and "County roads". The database provides information on posted speed, speed limit, departure angle and impact severity for both left and right side collisions. In the following the same terminology as the SAVeRS project ${ }^{(11)}$ has been adopted and Interstate roads and those US and State routes with at least two lanes per direction have bene classified as Motorways (MW). Those US and State routes with one lane per direction and all County roads are classified as Rural Roads (RR).

The departure angle was used to calculate the impact angle based on the side of the collision. The Impact Severity (IS) is defined as

$$
\text { I } S=\frac{1}{2} * m *(v \sin \theta)^{2}
$$

where, ' $m$ ' is the mass of the car, ' $v$ ' is the impact speed and ' $\theta$ ' is the impact angle. The

IS is an indication of the energy that the barrier has to withstand through deformation, displacement, breaking of joints etc. However, it does not take into account the varying effective mass of the impacting vehicle (which depends on the distance of the vehicle CG from the impact point). Collisions where the vehicle mass was greater than 2 tonnes were omitted from the analysis as the focus in this paper is on passenger cars.

\subsection{FE modelling of standard and non-standard barrier impacts}

The predicted responses of a model of a portable concrete Normal Containment barrier in a baseline scenario and in non-standard impact scenarios were evaluated through finite element analysis using the commercial software LS-Dyna. The baseline scenario was defined as the EN1317 TB31 crash configuration $\left(80 \mathrm{~km} / \mathrm{h}, 20^{\circ}\right)$ and the FE model response for this case was validated using the MIRA Test F188, a TB31 crash test for an N1 (Normal Containment) portable concrete barrier carried out at TRL, 
$\mathrm{UK}^{(12)}$. Seven non-standard vehicle-barrier impact scenarios were then defined based on the distribution of real-world ROR accidents. The non-standard impact scenarios consisted of a $1500 \mathrm{~kg}$ car hitting a portable concrete barrier at impact angles ranging between $15^{\circ}$ and $30^{\circ}$ and impact speeds between $80 \mathrm{~km} / \mathrm{h}$ and $125 \mathrm{~km} / \mathrm{h}$ ), as shown in Table 5. Impact position on the barrier was also varied. Table 5 also shows the cumulative probability of occurrence of each chosen FE modelling scenario based on the NCHRP accident data analysis.

EN1317 prescribes four criteria to assess the response of a barrier in a crash test: Acceleration Severity Index (ASI), Theoretical Head Impact Velocity (THIV), Exit Box (a prescribed vehicle trajectory after the impact), and barrier Working Width (barrier maximum deflection or displacement depending on the type of barrier). In this paper, the barrier performance in non-standard collision was evaluated using the acceleration time-histories, ASI score and the vehicle trajectory. The main emphasis was placed on the ASI score as values higher than 1 (for an A score) or 1.3 (for a B score) are sufficient for failing the barrier design in the test.

The barrier model was obtained by modifying an FE model available from the National Crash Analysis Center (NCAC) archive ${ }^{(20)}$ to better represent the crash tested barrier used for validation purposes ${ }^{(12)}$. The barrier is made of $3 \mathrm{~m}$ long $\mathrm{F}$-shape concrete units connected by steel hooks and U-shaped anchors. The FE model of each unit is composed of a base, a cover plate, tapered shims and separator blocks. A rigid material was used for the barrier units. The barrier was placed on a rigid surface with a barrier-ground friction coefficient of 0.3 . Figure 2 shows the cross-section and joints of the barrier model and Figure 3 shows the drawings of the F-shape portable concrete barrier $806 \mathrm{~mm}$ high barrier tested in TRL.

The vehicle used for the MIRA Test F188 was a 3500cc Rover SD1 first registered in 1980, see Figure 4-b. Since it would have been out of the scope of this work to develop an FE model of this vehicle, an FE model available from the (NCAC) archive ${ }^{(20)}$ was used for the analysis. The Toyota Camry V01 (2012) FE model, see 
Figure 4-a, has 1.7 million nodes, 1.7 million elements and 663 parts. The average element size used is $6-7 \mathrm{~mm}$. The vehicle was validated by NCAP with a frontal crash test at $56 \mathrm{Km} / \mathrm{h}$. The mass of the original NCAC vehicle, $1452 \mathrm{~kg}$, was modified to match the mass of the crash test vehicle used for validating the FE analysis, $1535 \mathrm{~kg}$. In Table 6 the main geometrical characteristics of the physical test vehicle and FE model are given.

Considering the physical test and the modelling involve different vehicle makes, models and registration periods with resulting differences in size and stiffness, the model response is not expected to exactly match the physical test data. However, the EN1317 does not specify the vehicle model to be used and the comparisons presented here should give a reasonable assessment of the capacity of the FE model to represent the kinematic response of the vehicle in a barrier impact.

\section{Baseline model validation}

The FE model validation was carried out by comparing the acceleration time histories, the Acceleration Severity Index (ASI) and the vehicle trajectory during the impact. The ASI values were obtained according to:

$A S I=\max \{A S I(t)\} ; A S I(t)=\sqrt{\left(\frac{\bar{a}_{x}(t)}{12 g}\right)^{2}+\left(\frac{\bar{a}_{y}(t)}{9 g}\right)^{2}+\left(\frac{\bar{a}_{z}(t)}{10 g}\right)^{2}}$,

with $a_{x}, a_{y}, a_{z}$ being the acceleration components at the CG of the vehicle in the vehicle reference system. For each simulation the Impact Severity (IS) was also calculated according to Eq 1.

The original acceleration time histories of the MIRA F188 crash test were recorded using a Butterworth constant phase delay filter with cut-off frequency of $60 \mathrm{~Hz}$ (CFC60 Filter to SAE J211a) and filtered with a cut-off frequency of $10 \mathrm{~Hz}$ before being analysed. For validation purposes the same filtering was applied to the FE model accelerations of the $80 \mathrm{~km} / \mathrm{h}, 20^{\circ}$ impact scenario (baseline model). Once the model was validated the acceleration time histories of each impact scenario (baseline model 
included) were filtered according to EN1317 part 1, i.e. using a four-pole phaseless Butterworth digital filter with cut-off frequency of $13 \mathrm{~Hz}$.

The model was also validated using both the Sprague-Geers and ANOVA metrics as adapted in the NCHRP project 22-24 ${ }^{(16)}$ (Recommended Procedures for Verification and Validation of Computer Simulations used for Roadside Safety Applications) and the analysis was run using the Roadside Safety Verification and Validation Program (RSVVP) ${ }^{(21)}$, the computer software developed by the authors of the NCHRP project 22-24.

\section{Results}

\subsection{Statistical analysis}

The accident database from project NCHRP 17-22 contains 890 SVROR accidents occurred between 1997-2004, of which 505 cases meet the inclusion criteria. For Rural Roads (RR), in 132 cases the cars hit the left side and in 146 cases cars hit the right side (left side is the median side in the US). For Motorways (MW), in 105 cases the cars hit the left side and in 122 cases the cars hit the right side. The descriptive statistics are shown in Figure 5. In 55 cases (36MW+19RR) on the right side and 69 cases $(20 \mathrm{MW}+49 \mathrm{RR})$ on the left side of the road, the impact angle was higher than $20^{\circ}$.

Table 7 shows that for accidents of the Right $(R)$ side of the road, the speed limits are not strongly correlated with impact speed (correlation coefficients below 0.5 ). Accordingly, the Rural Roads $\mathrm{R}$ and Motorway $\mathrm{R}$ data were analysed as a single dataset to assess the suitability of the existing EN1317 specification of using an impact angle of $20^{\circ}$, see Figure 6.

\subsection{FE simulations}

The model validation results are shown first. Figure 7 shows snapshots of the model and physical vehicle trajectory. Figure 8 shows the corresponding acceleration 
time history along the longitudinal, lateral and vertical direction in the vehicle reference system for the baseline model and the TRL crash test. Figure 9 shows the yaw angle time relationships. Table 8 summarises the validation results. The ASI time history, (see Figure $8-d$ ) shows a peak relative error of $10 \%$. The predicted time peak is delayed by $10 \mathrm{~ms}$ (19\% error).

The validation results according to the NCHRP project 22-24 are reported in Table 9. The Sprague-Geers MPC values of the $X, Y$ and $Z$ acceleration in the vehicle reference system and the yaw and roll time histories are all within the allowable limits $([-40,40]){ }^{(21)}$. As for the ANOVA metrics, the $Y$ and $Z$ acceleration signals fall beyond the limit intervals, however the metrics of the combined acceleration channels, a procedure set in NCHRP project 22-24 for similar cases, are within the limit values.

The results of model validation show that the model is capturing the important physical processes of the system with appropriate magnitude and time response.

The acceleration severity index (ASI) of the baseline and non-standard scenario models are given in Table 5. Figure 10 shows the predicted relationships between ASI score and impact angle and ASI score and impact speed.

\section{Discussion}

This paper assesses the suitability of the impact speed and angle conditions for the European EN 1317 barrier impact standard. In the absence of European data, a subset of the US NCHRP data (presented in Figure 5) shows that in majority of cases, impact speed was lower than both the speed limit and design speed of the road. Hence it can be assumed that testing of barriers at higher speeds than the design speed may not be a necessity. However, for impact angles it can be observed that for Motorway Right accidents (i.e. when run-off is not to the median side), a considerable percentage of crashes $(30 \%)$ had impact angles greater than $20^{\circ}$, see Figure 5 -b. For rural roads right the percentage of crashes with angles greater than 20 degrees is $13 \%$. 
Considering both Motorway and Rural road cases, Figure 6 shows that, similar to Mak (1980) \& Albuquerque (2010), the impact speed follows a normal distribution. However, the impact angle distribution follows a gamma distribution, while Mak (1980) presented a generalized extreme value distribution and Albuquerque (2010) presented a normal distribution. Albuquerque (2010) showed that both impact speed and angle followed a normal distribution and a joint probability distribution of bivariate normal was used to model the accident probability. The current dataset shows that the impact speed and angle are not strongly correlated (Table 7). Calculation of the joint probability distribution considering a normal marginal distribution for impact speed and a gamma marginal distribution for impact angle will be a future focus, but is out of scope of this paper. The average impact speed is $82.2 \mathrm{~km} / \mathrm{h}$, and for almost half the case the impact speed is less than $80 \mathrm{~km} / \mathrm{h}$. The speed is higher than $110 \mathrm{~km} / \mathrm{h}$ (TB32 test specification) only in $11 \%$ of cases. Considering the impact angle, the analysis shows there is around $20 \%$ chance of exceeding an angle of $20^{\circ}$ and there is a $90 \%$ probability of having accidents at impact angles up to $25^{\circ}$. These are US data, and a review of run-off road accidents in Europe should be performed, but the data presented here suggest a potential reassessment of the EN 1317 barrier impact angle to include a steeper angle.

The finite element modelling was performed to assess the potential influence of different impact conditions on the resulting ASI score in roadside barrier tests.

Comparison of the baseline model predictions to the TRL physical test data show very similar displacements, see Figure 7, where the vehicle angle and position along the barrier are practically the same. This is also confirmed up to $300 \mathrm{~ms}$ by the yaw time history plotted in Figure 9. Figure 8 and Table 8 show relative acceleration errors in the region of about $20 \%$, with a tendency for over-prediction by the numerical model, possibly due to increased stiffness of the more modern FE vehicle model. The FE vehicle model (Toyota Camry V01) is different to the test vehicle (3500cc Rover SD1), accounting for some of the differences in the test and simulation results. As the 
purpose of the model is to study the influence of different input parameters on the system response, the exact verification of model performance is not a pre-requisite. The $19 \%$ error in the time peak (Table 8 ) is influenced by the $10 \mathrm{~Hz}$ filtering of the original recorded accelerations as shown by the longitudinal acceleration value at time zero.

Figure 10 not surprisingly shows very significant increases in ASI score with increasing impact speed, but also with angle, highlighting the need to have an appropriate angle specified in the EN1317 barrier standard. In Figure 11 the ASI scores for all simulations is shown versus the corresponding IS and a comparison is drawn with the previously published results from Montella et al. Although the general trend is the same, the predicted ASI from the current modelling is more severe than predicted by Montella et al. The reasons for this are not clear, although the Montella et al model results were not explicitly validated.

\section{Conclusions}

The accident data analysis for run-off road accidents indicates that a substantial proportion of accidents (up to $30 \%$ for Motorways from the US NCHRP 17-22 database) had impact angles in excess of $20^{\circ}$, even though this is the angle specified in the European EN 1317 barrier impact standard. The finite element modelling indicates a very significant influence of impact angle on impact severity, thereby illustrating the importance of a suitable impact angle for a standard test. Accordingly, evaluation of current barriers at low impact angles may not adequately capture the injury risks posed by those barriers at higher impact angles, as seen in the accident data. A review of European run-off road accidents and a possible review of EN 1317 should be performed. 


\section{Acknowledgment}

Gavin Williams of TRL for sharing the experimental barrier impact data ${ }^{(12)}$. 


\section{References}

(1) AASHTO. Manual for Assessing Safety Hardware (MASH). 2009.

(2) Albuquerque FDB, Sicking DL, Stolle CS. Roadway Departure and Impact Conditions. Transportation Research Record: Journal of the Transportation Research Board 2010;2195(1):106-114.

(3) Atahan AO. Finite-element crash test simulation of New York Portable Concrete Barrier with I-shaped connector. Journal of Structural Engineering-Asce 2006 Mar;132:430-440.

(4) Bateman MB, Howard IC, Johnson AR, Walton JM. Computer simulation of the impact performance of a wire rope safety fence. Int J Impact Eng 2001;25:67-85.

(5) Borovinsek M, Vesenjak M, Ulbin M, Ren Z. Simulation of crash tests for high containment levels of road safety barriers. Eng Failure Anal 2007;14:1711.

(6) Brinkman CP, Mak KK. Accident Analysis of Highway Narrow Bridge Sites. Public Roads 1986;49(HS-040 181).

(7) CEN European Committee for Standardization. BS EN1317-1:2010 - Road restraint systems. Terminology and general criteria for test methods 2010.

(8) CEN European Committee for Standardization. BS EN1317-2:2010 - Road restraint systems. Performance classes, impact test acceptance criteria and test methods for safety barriers including vehicle parapets 2010 .

(9) Erginbas C, Tanzi N, Williams G, Amato G. <br />SAVeRS Project D1.1 Report, Defining the Different Parameters which can influence the need and selection of VRS. 2014.

(10) Ferdous MR, Abu-Odeh A, Bligh RP, Jones HL, Sheikh NM. Performance limit analysis for common roadside and median barriers using LS-DYNA. International Journal of Crashworthiness 2011;16:691-706.

(11) La Torre F, Erginbas C, Williams G, Thomson R, Hemmings G, Stefan C. <br />SAVeRS Project D3.1 Report, Guideline for the selection of the most appropriate Roadside Vehicle Restraint System 2015.

(12) Laker I. MIRA Test F188, The impact of a 1.5 tonne Rover SD1 car into a portable concrete barrier at $20^{\circ} .1988$.

(13) Mak KK, Mason RL. Accident Analysis: Breakaway and Nonbreakaway Poles Including Sign and Light Standards Along Highways. : The Administration; 1980.

(14) Martínez CJ. The operational and safety impacts of run-off-road crashes in Wisconsin: tree, fence and pole hits. University of Wisconsin-Madison Department of Civil and Environmental Engineering: Traffic Operations and Safety Laboratory; 2008. 
(15) Marzougui D, Bahouth G, A. E, L. M, H. T. Evaluation of Portable Concrete Barriers Using Finite Element Simulation. Transportation Research Record: Journal of the Transportation Research Board 2000(1720):1-6.

(16) Mongiardini M, Ray MH, Anghileri M. Acceptance criteria for validation metrics in roadside safety based on repeated full-scale crash tests. International Journal of Reliability and Safety 2009;4(1):69-88.

(17) A. Montella and M. Pernetti. Vehicle Occupant Impact Severity in Relation to Real World Impact Conditions. SIIV 2004, 2nd International Congress on New Technologies and Modeling Tools for Roads-Applications to Design and Management; 27 - 29 October 2004; Vehicle Occupant Impact Severity in Relation to Real World Impact Conditions. ; 2004.

(18) Naing CL, Hill J, Thomson R, Fagerlind H, Kelkka M, Klootwijk C, et al. Singlevehicle collisions in Europe: analysis using real-world and crash-test data. International Journal of Crashworthiness 2008 03/25; 2013/04;13:219-229.

(19) National Crash Analysis Center. 2012 Toyota Camry FEM version 1 Report. 2012.

(20) National Crash Analysis Center. Finite Element Model Archive. 2012.

(21) Ray MH, Plaxico CA, Anghileri M. Procedures for Verification and Validation of Computer Simulations Used for Roadside Safety Applications. : National Cooperative Highway Research Program, Transportation Research Board of the National Academies; 2010.

(22) RISER Consortium. European best practice for roadside design: guidelines for roadside infrastructure on new and existing roads. 2005.

(23) Ross HEJ, Sicking DL, A. ZR, D. MJ. NCHRP Report 350 Recommended Procedures for the Safety Performance Evaluation of Highway Features. http://trid.trb.org/view.aspx?id=372484: Transportation Research Board National Research Council; 1993.

(24) Tomasch E, Hoschopf H, Gobald M, Steffan H, Nadler B, Nadler F, et al. Single vehicle run-off-road accidents colliding turned down terminals of guardrails. Berichte der Bundesanstalt für Straßenwesen. Unterreihe Fahrzeugtechnik 2010(77).

(25) Wijnen W, Mesken J, Vis MA. Effectiviteit en kosten van verkeersveiligheidsmaatregelen. : Stichting Wetenschappelijk Onderzoek Verkeersveiligheid; 2010.

(26) Wu W, Thomson R. Compatibility between passenger vehicles and road barriers during oblique collisions. International journal of crashworthiness 2004;9(3):245-253. 
Table list

Table 1 SVROR impact speed and angle for published rural road databases

Table 2 Crash tests defined in EN1317 for passenger cars

Table 3 Containment levels in EN1317 for passenger cars

Table 4 MASH test matrix for barriers

Table 5 Simulation Matrix

Table 6 Vehicle geometry for validation (Crash test)

Table 7 Correlation matrix between impact speed and angle and impact speed and speed limit.

Table 8 Validation of FE model

Table 9 Validation of FE model based on NCHRP project 22-24

\section{Figure list}

Figure 1: impact point on the barrier unit: a) baseline model and simulations 3-8; b) simulation 2.

Figure 2 Barrier FE model (units and joints)

Figure 3 Concrete units and joints used for model validation (12)

Figure 4 (a) Toyota Camry FE model (19); (b) Rover SD1 used for the TB31 crash test. Figure 5: Distribution of impact speed (a) and impact angles (b) for Rural roads (RR) and Motorways (MW)

Figure 6: Fitted distributions for impact speed and impact angles for Rural Road Right (RR R) and Motorway Right (MW R) cases.

Figure 7 Vehicle and barrier displacement at the start, peak and end of the front impact for the validated case $\left(20^{\circ}\right.$ angle and $\left.80 \mathrm{~km} / \mathrm{h}\right)$.

Figure 8 Acceleration components and Acceleration Severity time history of the crash test at $20^{\circ}$ angle and $80 \mathrm{~km} / \mathrm{h}$ (validated case)

Figure 9 Yaw time history of the crash test at $20^{\circ}$ angle and $80 \mathrm{~km} / \mathrm{h}$ (validated case) Figure 10 FE model predictions for (a) ASI vs impact angle; (b) ASI vs impact speed Figure 11 ASI vs Impact Severity (IS) of the FE simulations 
Table 10 SVROR impact speed and angle for published rural road databases

\begin{tabular}{|c|c|c|c|c|c|}
\hline $\begin{array}{l}\text { Study and } \\
\text { database }\end{array}$ & $\begin{array}{l}\text { Years of } \\
\text { collisions }\end{array}$ & Type of roads & $\begin{array}{l}\text { N. of } \\
\text { collisions }\end{array}$ & \begin{tabular}{|l|} 
Impact speed \\
$\left(90^{\text {th }}\right.$ \\
percentile $)$
\end{tabular} & $\begin{array}{l}\text { Impact/Exit angle } \\
\left(90^{\text {th }} \text { percentile }\right)\end{array}$ \\
\hline $\begin{array}{l}\text { RISER }{ }^{(6)} \\
\text { (Europe) }\end{array}$ & 1999-2002 & $\begin{array}{l}\text { Roads with speed } \\
\text { limit } \geq 70 \mathrm{~km} / \mathrm{h}\end{array}$ & 82 & $120 \mathrm{~km} / \mathrm{h}$ & $\begin{array}{l}20^{\circ} \\
\text { (exit angle) }\end{array}$ \\
\hline $\begin{array}{l}\text { Mak }{ }^{(7,8)} \\
\text { (US) }\end{array}$ & 1970s & $\begin{array}{l}\text { Highways } \\
(90 \mathrm{~km} / \mathrm{h})\end{array}$ & (?) & $95 \mathrm{~km} / \mathrm{h}$ & $\begin{array}{l}32^{\circ} \\
\text { (impact angle) }\end{array}$ \\
\hline $\begin{array}{l}\text { Albuquerque } \\
(9-11) \\
\text { (US) }\end{array}$ & 1997-2002 & $\begin{array}{l}\text { Roads with speed } \\
\text { limit between } 80 \\
\text { and } 120 \mathrm{~km} / \mathrm{h}\end{array}$ & 890 & $92-106 \mathrm{~km} / \mathrm{h}$ & $\begin{array}{l}30-34^{\circ} \\
\text { (impact angle) }\end{array}$ \\
\hline
\end{tabular}

Table 11 Crash tests defined in EN1317 for passenger cars

\begin{tabular}{|l|l|l|l|l|}
\hline \multicolumn{5}{|l|}{ Table $1-$ Vehicle impact test descriptions } \\
\hline Test & $\begin{array}{l}\text { Impact } \\
\text { speed }(\mathrm{km} / \mathrm{h})\end{array}$ & $\begin{array}{l}\text { Impact angle } \\
\left({ }^{\circ}\right)\end{array}$ & $\begin{array}{l}\text { Total } \\
\text { mass }(\mathrm{kg})\end{array}$ & Type of vehicle \\
\hline TB 11 & 100 & 20 & 900 & car \\
\hline TB 21 & 80 & 8 & 1300 & car \\
TB 22 & 80 & 15 & 1300 & car \\
TB 31 & 80 & 20 & 1500 & car \\
TB 32 & 110 & 20 & 1500 & car \\
\hline
\end{tabular}

Table 12 Containment levels in EN1317 for passenger cars

\begin{tabular}{|l|l|l|}
\hline \multicolumn{2}{|l|}{ Table 2 - Containment levels } \\
\hline Containment levels & Acceptance test \\
\hline Low angle containment & T1 & TB21 \\
\cline { 2 - 3 } & T2 & TB22 \\
\cline { 2 - 3 } & T3 & TB21 \\
\hline \multirow{4}{*}{ Normal containment } & N1 & TB31 \\
\cline { 2 - 3 } & N2 & TB32 and TB11 \\
\hline Higher containment & H1 & TB 11 \\
\cline { 2 - 3 } & L1 & TB32 and TB 11 \\
\cline { 2 - 3 } & H2 & TB 11 \\
\cline { 2 - 3 } & L2 & TB32 and TB 11 \\
\cline { 2 - 3 } & H3 & TB 11 \\
\cline { 2 - 3 } & L3 & TB32 and TB 11 \\
\hline Very high containment & H4a & TB 11 \\
& H4b & TB 11 \\
\cline { 2 - 3 } & L4a & TB32 and TB 11 \\
& L4b & TB32 and TB 11 \\
\hline
\end{tabular}


Table 13 MASH test matrix for barriers

\begin{tabular}{|c|c|c|c|}
\hline $\begin{array}{l}\text { Test } \\
\text { level }\end{array}$ & $\begin{array}{l}\text { Mass (kg) and type of vehicle } \\
\mathrm{C} \text { (passenger car); } \mathrm{P} \text { (pickup truck); } \mathrm{S} \text { (single unit } \\
\text { truck); } \mathrm{V} \text { (tractor/Van trailer); } \mathrm{T} \text { (tractor/Tanker trailer). }\end{array}$ & $\begin{array}{l}\text { Impact speed } \\
(\mathrm{km} / \mathrm{h})\end{array}$ & $\begin{array}{l}\text { Impact } \\
\text { angle }\left(^{\circ}\right)\end{array}$ \\
\hline \multirow{2}{*}{ Level 1} & $1100 \mathrm{C}$ & \multirow{2}{*}{50} & \multirow{2}{*}{25} \\
\hline & $2270 \mathrm{P}$ & & \\
\hline \multirow{2}{*}{ Level 2} & $1100 \mathrm{C}$ & \multirow{2}{*}{70} & \multirow{2}{*}{25} \\
\hline & $2270 \mathrm{P}$ & & \\
\hline \multirow{2}{*}{ Level 3} & $1100 \mathrm{C}$ & \multirow{2}{*}{100} & \multirow{2}{*}{25} \\
\hline & $2270 \mathrm{P}$ & & \\
\hline \multirow{3}{*}{ Level 4} & $1100 \mathrm{C}$ & \multirow{2}{*}{100} & \multirow{2}{*}{25} \\
\hline & $2270 \mathrm{P}$ & & \\
\hline & $10000 \mathrm{~S}$ & 90 & 15 \\
\hline \multirow{3}{*}{ Level 5} & $1100 \mathrm{C}$ & \multirow{2}{*}{100} & \multirow{2}{*}{25} \\
\hline & $2270 \mathrm{P}$ & & \\
\hline & $36000 \mathrm{~V}$ & 80 & 15 \\
\hline \multirow{3}{*}{ Level 6} & $1100 \mathrm{C}$ & \multirow{2}{*}{100} & \multirow{2}{*}{25} \\
\hline & $2270 \mathrm{P}$ & & \\
\hline & $36000 \mathrm{~T}$ & 80 & 15 \\
\hline
\end{tabular}

Table 14 Simulation Matrix

\begin{tabular}{|c|c|c|c|c|c|c|c|}
\hline Simulation & $\begin{array}{l}\text { Impact } \\
\text { Speed }\end{array}$ & $\begin{array}{l}\text { Accident } \\
\text { data with } \\
\text { speed } \\
\text { below the } \\
\text { speed in } \\
\text { the } \\
\text { simulation }\end{array}$ & $\begin{array}{l}\text { Impact } \\
\text { angle }\end{array}$ & $\begin{array}{l}\text { Accident data } \\
\text { with impact } \\
\text { angle below } \\
\text { the impact } \\
\text { angle in the } \\
\text { simulation }\end{array}$ & $\begin{array}{l}\text { Impact location } \\
\text { on the barrier }\end{array}$ & \begin{tabular}{|l|} 
Impact \\
Severity \\
(IS)
\end{tabular} & $\begin{array}{l}\text { Acceleration } \\
\text { severity } \\
\text { index (ASI) } \\
\text { (FE model) }\end{array}$ \\
\hline & $(\mathrm{km} / \mathrm{h})$ & (\%) & (Deg) & $\%$ & & $(k J)$ & \\
\hline $\begin{array}{l}1 \text { baseline } \\
\text { (validated } \\
\text { case) }\end{array}$ & 80 & $46 \%$ & $20^{\circ}$ & $80 \%$ & $\begin{array}{l}\text { As in crash test } \\
\text { (22) }\end{array}$ & 44 & 1.01 \\
\hline 2 & 80 & $46 \%$ & $20^{\circ}$ & $80 \%$ & $\begin{array}{l}\text { Midpoint of the } \\
\text { barrier unit }\end{array}$ & 44 & 1.32 \\
\hline 3 & 80 & $46 \%$ & $30^{\circ}$ & $95 \%$ & $\begin{array}{l}\text { As in crash test } \\
\text { (22) }\end{array}$ & 95 & 1.51 \\
\hline 4 & 70 & $30 \%$ & $10^{\circ}$ & $37 \%$ & $\begin{array}{l}\text { As in crash test } \\
\text { (22) }\end{array}$ & 9 & 0.40 \\
\hline 5 & 70 & $30 \%$ & $30^{\circ}$ & $95 \%$ & $\begin{array}{l}\text { As in crash test } \\
\text { (22) }\end{array}$ & 73 & 1.30 \\
\hline 6 & 125 & $96 \%$ & $15^{\circ}$ & $63 \%$ & $\begin{array}{l}\text { As in crash test } \\
\text { (22) }\end{array}$ & 62 & 1.33 \\
\hline 7 & 125 & $96 \%$ & $30^{\circ}$ & $95 \%$ & $\begin{array}{l}\text { As in crash test } \\
\text { (22) }\end{array}$ & 231 & 2.20 \\
\hline 8 & 110 & $89 \%$ & $20^{\circ}$ & $80 \%$ & $\begin{array}{l}\text { As in crash test } \\
\text { (22) }\end{array}$ & 84 & 1.48 \\
\hline
\end{tabular}


Table 15 Vehicle geometry for validation (Crash test)

\begin{tabular}{|l|l|l|}
\hline & $\begin{array}{l}\text { Crash test vehicle } \\
\text { (ROVER SD1 1980) }\end{array}$ & $\begin{array}{l}\text { FE model vehicle } \\
\text { (TOYOTA Camry 2012) }\end{array}$ \\
\hline CG $\times(\mathrm{m})$ & 1.22 & 1.14 \\
\hline CG z $(\mathrm{m})$ & 0.48 & 0.55 \\
\hline Car length $(\mathrm{m})$ & 4.67 & 3.75 \\
\hline Car width $(\mathrm{m})$ & 1.77 & 1.44 \\
\hline Wheelbase $(\mathrm{m})$ & 2.81 & 2.16 \\
\hline Wheel track $(\mathrm{m})$ & 1.51 & 1.24 \\
\hline
\end{tabular}

Table 16 Correlation matrix between impact speed and angle and impact speed and speed limit.

\begin{tabular}{|l|l|l|l|l|}
\hline & $\begin{array}{l}\text { Rural roads } \\
\mathrm{L}\end{array}$ & $\begin{array}{l}\text { Rural roads } \\
\mathrm{R}\end{array}$ & $\begin{array}{l}\text { Motorways } \\
\mathrm{R}\end{array}$ & $\begin{array}{l}\text { Motorways } \\
\mathrm{L}\end{array}$ \\
\hline $\begin{array}{l}\text { Number of } \\
\text { observations }\end{array}$ & 132 & 146 & 122 & 105 \\
\hline $\begin{array}{c}\text { Impact Speed } \\
\begin{array}{c}\text { Impact } \\
\text { Angle }\end{array}\end{array}$ & 0.34 & -0.26 & -0.29 & 0.38 \\
\hline $\begin{array}{c}\text { Impact Speed } \\
\text { Speed } \\
\text { Limit }\end{array}$ & 0.27 & 0.23 & -0.19 & 0.16 \\
\hline
\end{tabular}

Table 17 Validation of FE model

\begin{tabular}{|l|l|l|l|}
\hline & Crash Test & FE model & Relative error \\
\hline ASI peak time $(\mathrm{ms})$ & 54 & 64 & $19 \%$ \\
\hline ASI & 0.70 & 0.77 & $10 \%$ \\
\hline Longitudinal acceleration peak $(\mathrm{g})$ & 6.6 & 7.8 & $18 \%$ \\
\hline Lateral acceleration peak $(\mathrm{g})$ & 4.3 & 5.0 & $17 \%$ \\
\hline Vertical acceleration peak $(\mathrm{g})$ & 2.2 & 1.7 & $-22 \%$ \\
\hline
\end{tabular}


Table 18 Validation of FE model based on NCHRP project 22-24

\begin{tabular}{|l|c|c|c|c|c|c|c|}
\hline $\begin{array}{l}\text { NHCRP Project } \\
\text { 22-24 validation } \\
\text { analysis }\end{array}$ & $\begin{array}{c}\mathbf{X} \\
\text { acc. } \\
{[\mathrm{g}]}\end{array}$ & $\begin{array}{c}\mathbf{Y} \\
\text { acc. } \\
{[\mathrm{g}]}\end{array}$ & $\begin{array}{c}\mathbf{Z} \\
\text { acc. } \\
{[\mathrm{g}]}\end{array}$ & $\begin{array}{c}\text { Yaw } \\
\text { angle } \\
{\left[{ }^{\circ}\right]}\end{array}$ & $\begin{array}{c}\text { Roll } \\
\text { angle } \\
{\left[{ }^{\circ}\right]}\end{array}$ & $\begin{array}{c}\text { Multiple } \\
\text { Channels: } \\
\mathbf{X , ~ Y , ~ Z ~ a c c . ~}\end{array}$ & $\begin{array}{c}\text { Limit } \\
\text { values }\end{array}$ \\
\hline $\begin{array}{l}\text { Sprague-Geers } \\
\text { Magnitude [\%] }\end{array}$ & 8.4 & 27.7 & 12.3 & -0.9 & 6.2 & 18.9 & {$[-40,40]$} \\
\hline $\begin{array}{l}\text { Sprague-Geers } \\
\text { Phase [\%] }\end{array}$ & 17.1 & 21.1 & 34.1 & 5.3 & 20.5 & 20.8 & 40 \\
\hline $\begin{array}{l}\text { Sprague-Geers } \\
\text { Comprehensive [\%] }\end{array}$ & 19.1 & 34.8 & 36.2 & 5.4 & 21.6 & 28.9 & 40 \\
\hline $\begin{array}{l}\text { ANOVA Metrics - } \\
\text { Average [\%] }\end{array}$ & -1.7 & 14.4 & -22.0 & -2.9 & 4.2 & 4.2 & {$[-5,5]$} \\
\hline $\begin{array}{l}\text { ANOVA Metrics - } \\
\text { Std [\%] }\end{array}$ & 25.3 & 40.2 & 46.7 & 9.1 & 33.8 & 33.8 & $\mathbf{3 5}$ \\
\hline $\begin{array}{l}\text { Weights } \\
\text { (Multiple Channels) }\end{array}$ & 0.46 & 0.46 & 0.08 & $/$ & $/$ & $/$ & $/$ \\
\hline
\end{tabular}




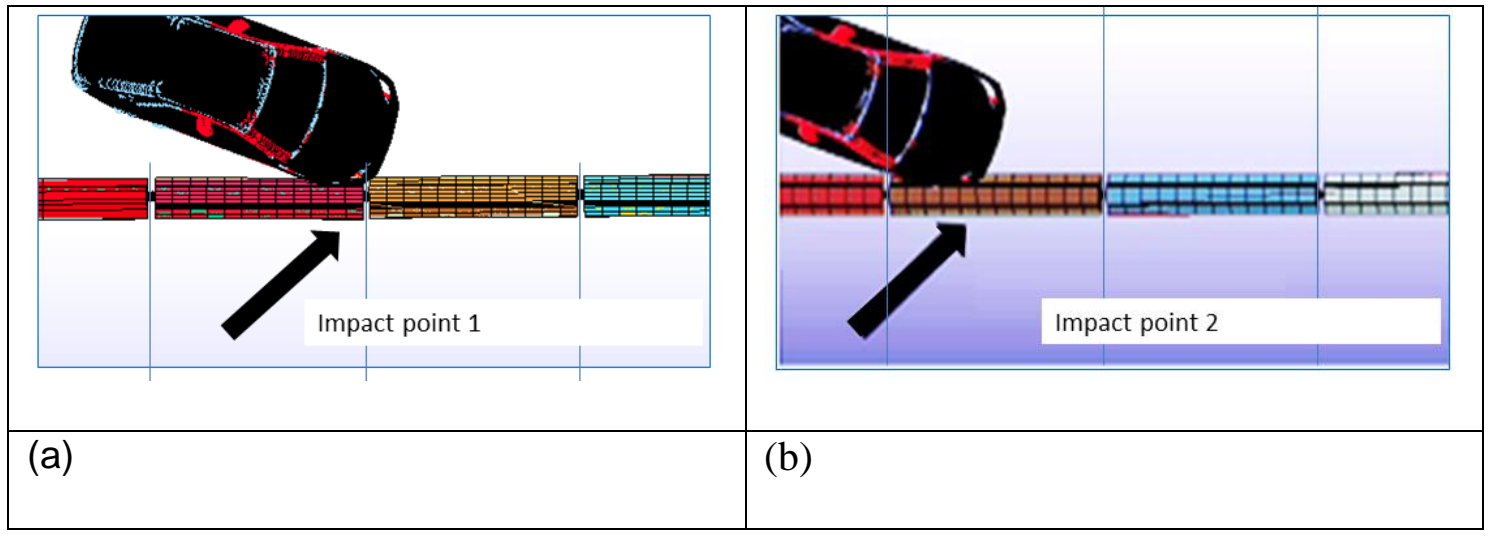

Figure 12: impact point on the barrier unit: a) baseline model and simulations 38; b) simulation 2. 

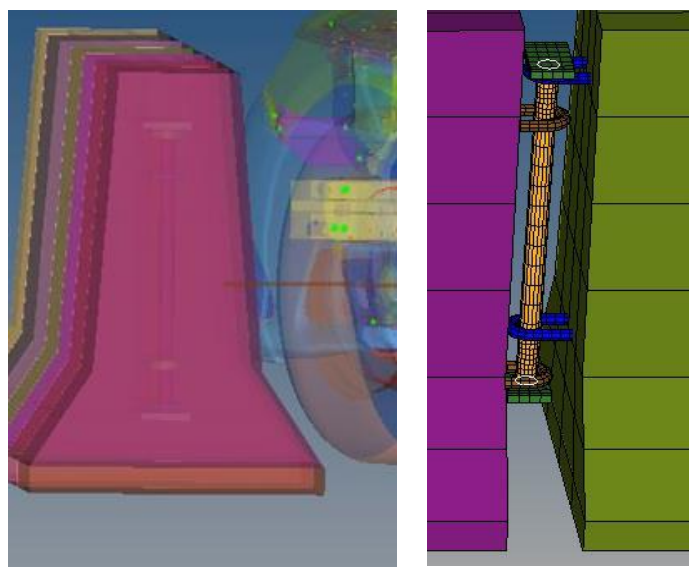

Figure 13 Barrier FE model (units and joint) 


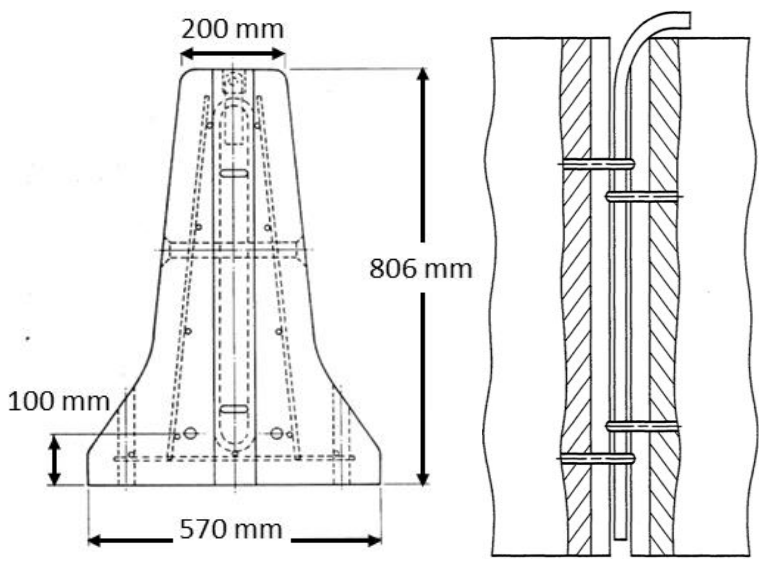

Figure 14 Concrete units and joints used for model validation (24) 


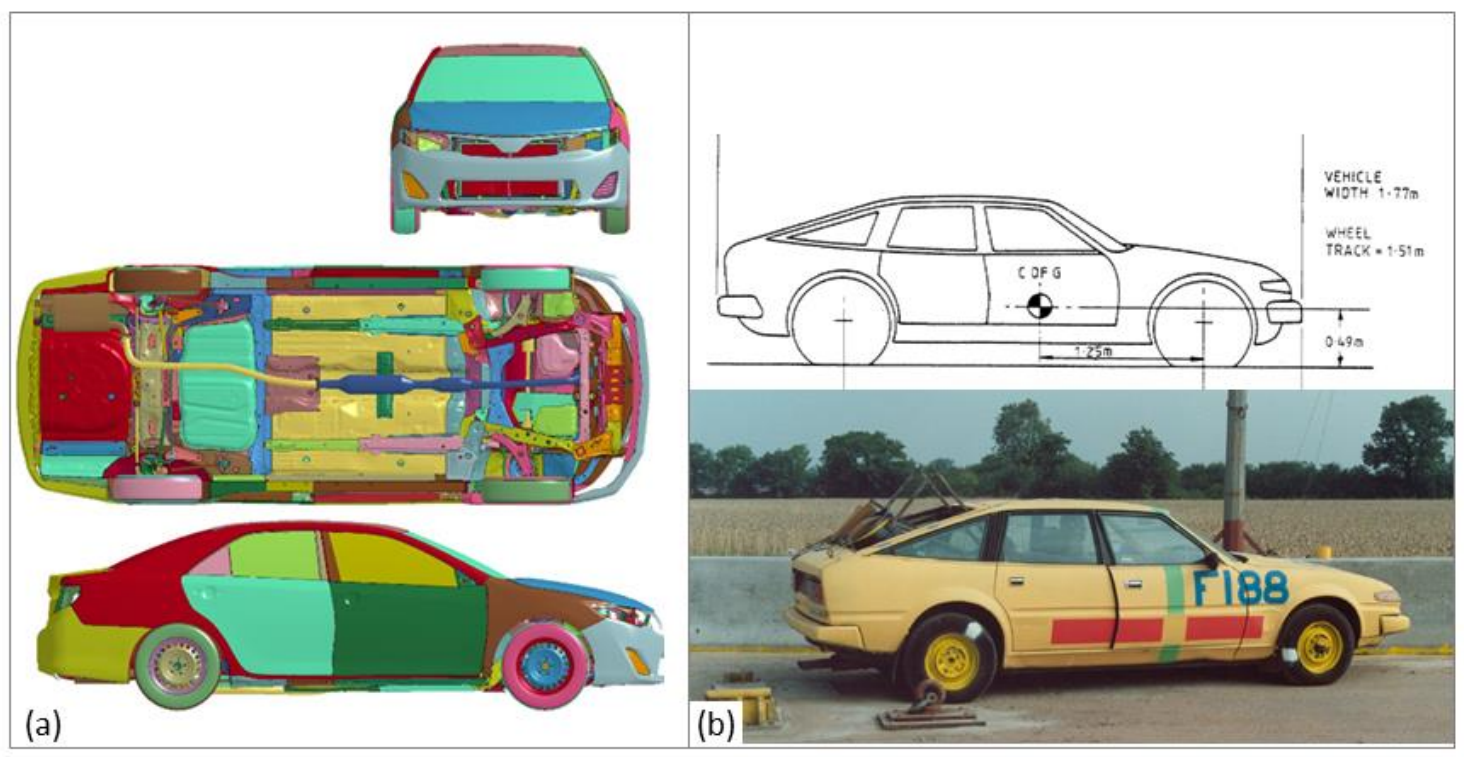

Figure 15 (a) Toyota Camry FE model (25); (b) Rover SD1 used for the TB31 crash test. 


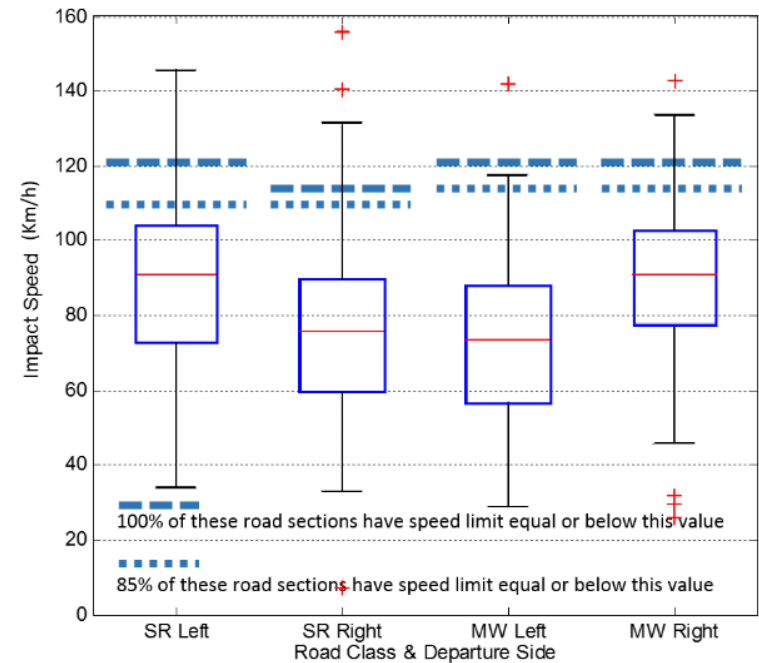

(a)

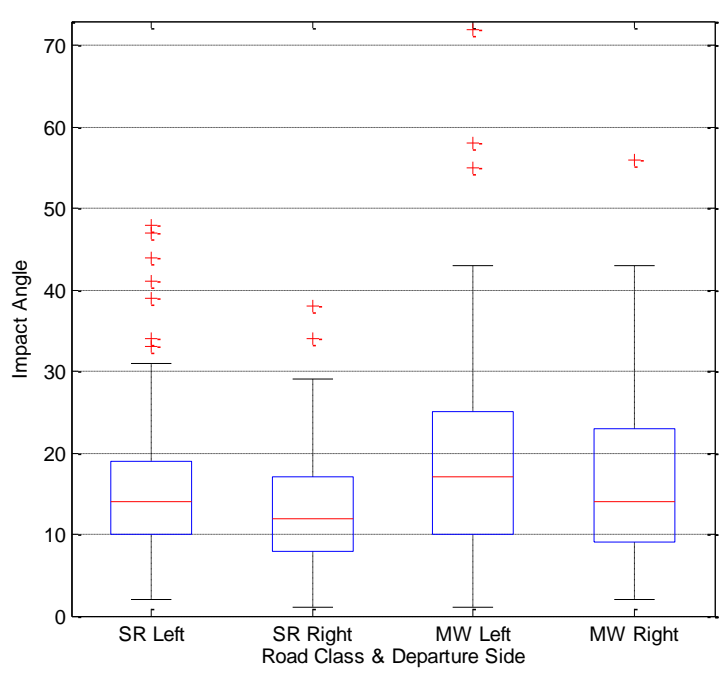

(b)

Figure 16: Distribution of impact speed (a) and impact angles (b) for Rural roads (SR) and Motorways (MW). 

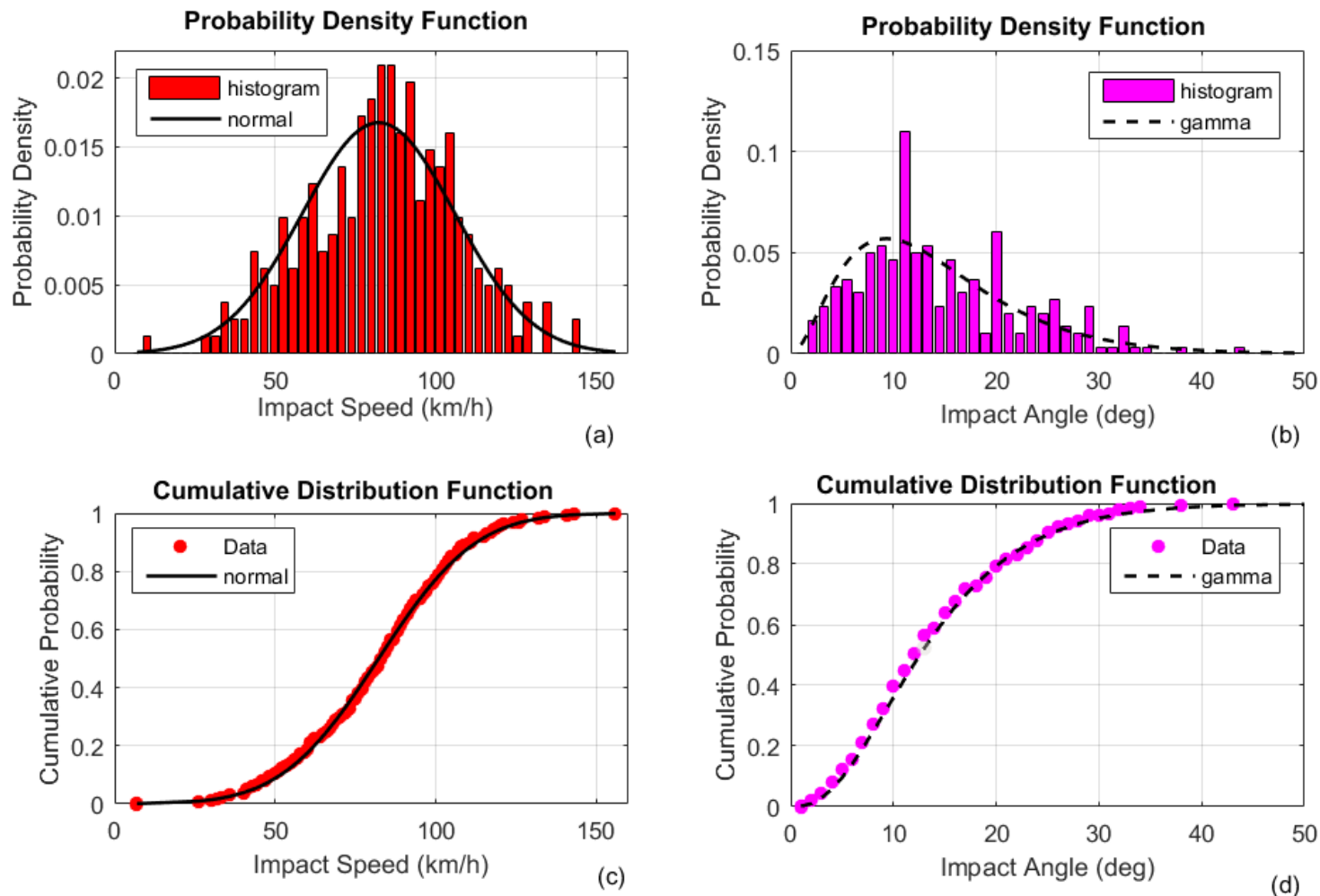

Figure 17: Fitted distributions for impact speed and impact angles for Rural Road Right (RR R) and Motorway Right (MW R) cases. 

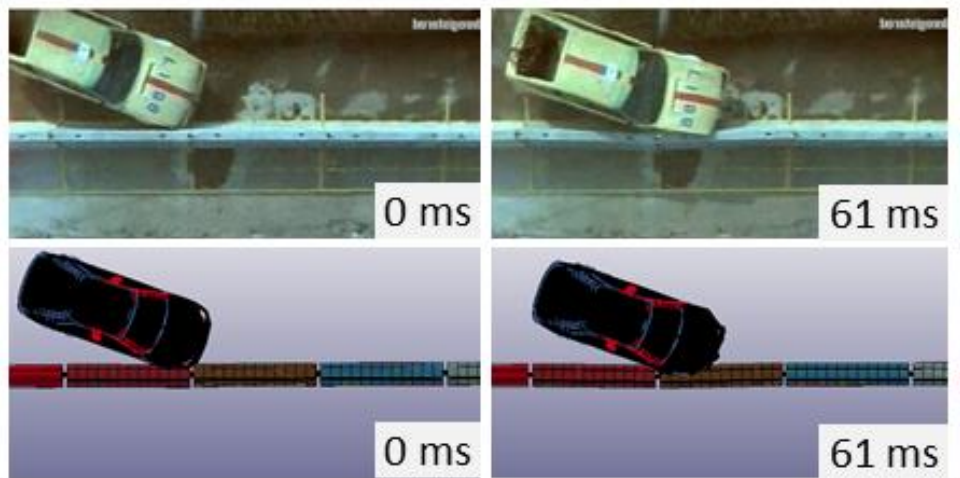
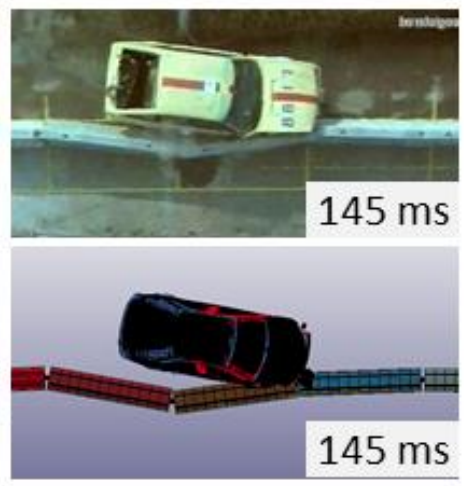

Figure 18: Vehicle and barrier displacement at the start, peak and end of the front impact for the validated case $\left(20^{\circ}\right.$ angle and $\left.80 \mathrm{~km} / \mathrm{h}\right)$. 

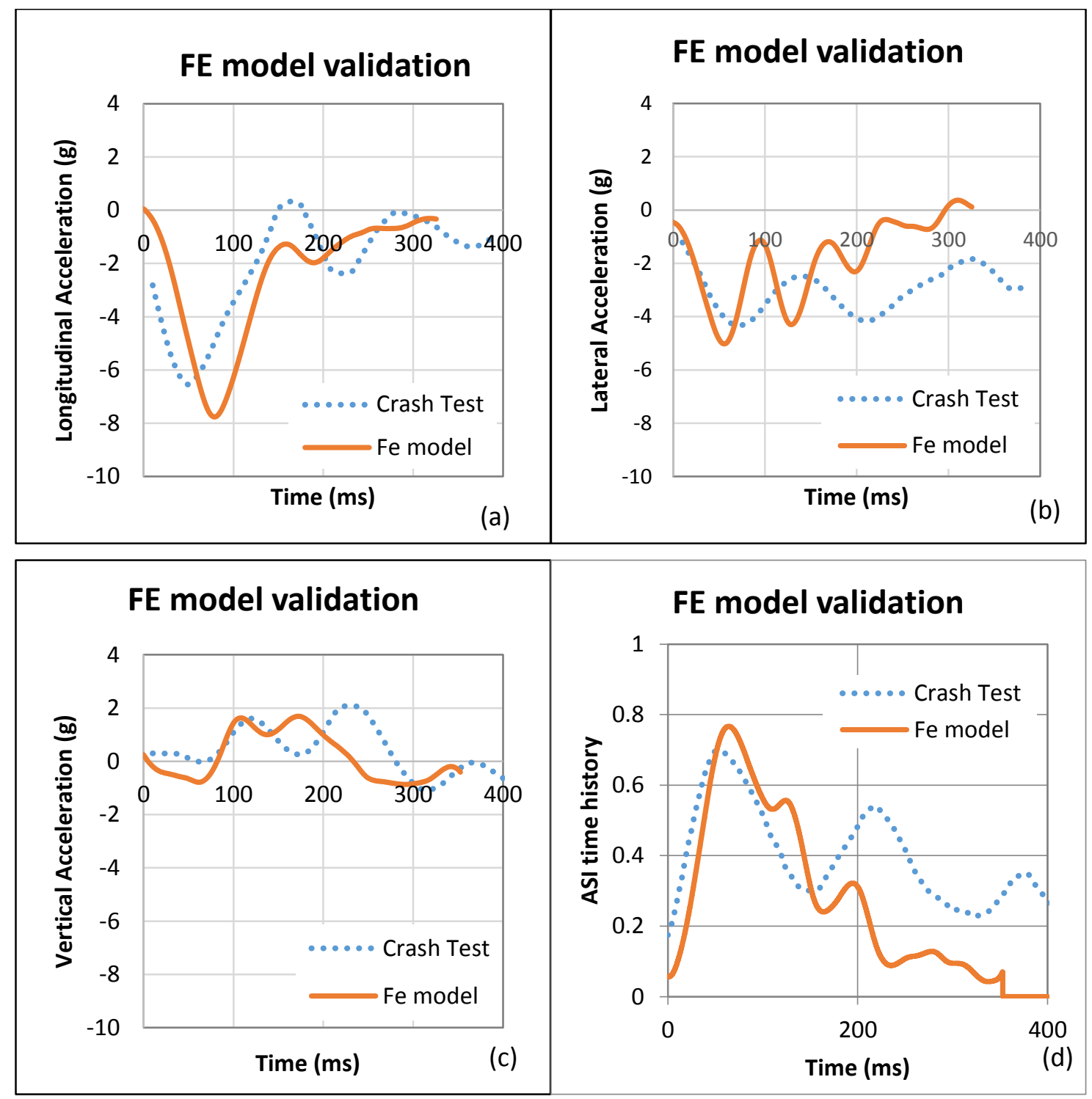

Figure 19: Acceleration components and Acceleration Severity time history of the crash test at $20^{\circ}$ angle and $80 \mathrm{~km} / \mathrm{h}$ (validated case) 


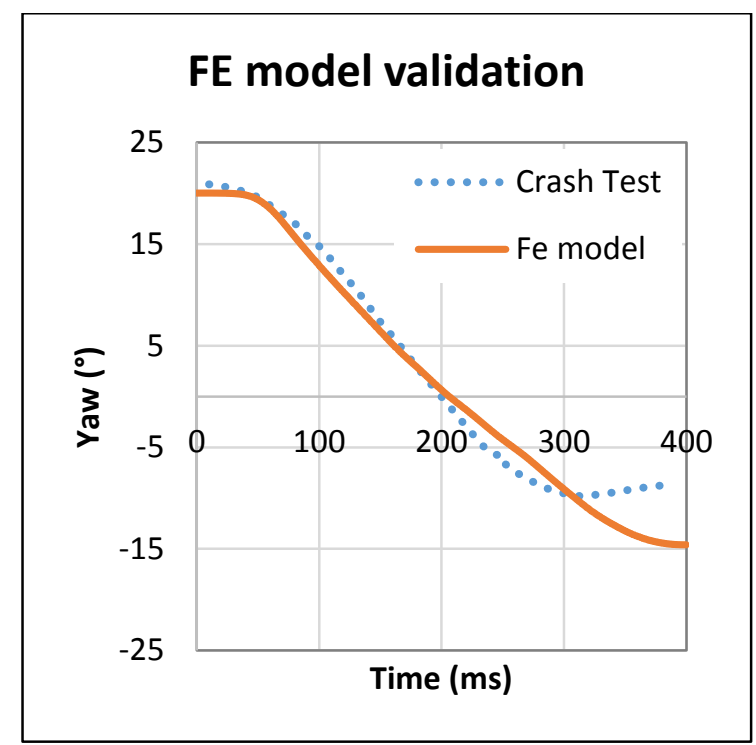

Figure 20: Yaw time history of the crash test at $20^{\circ}$ angle and $80 \mathrm{~km} / \mathrm{h}$ (validated case) 


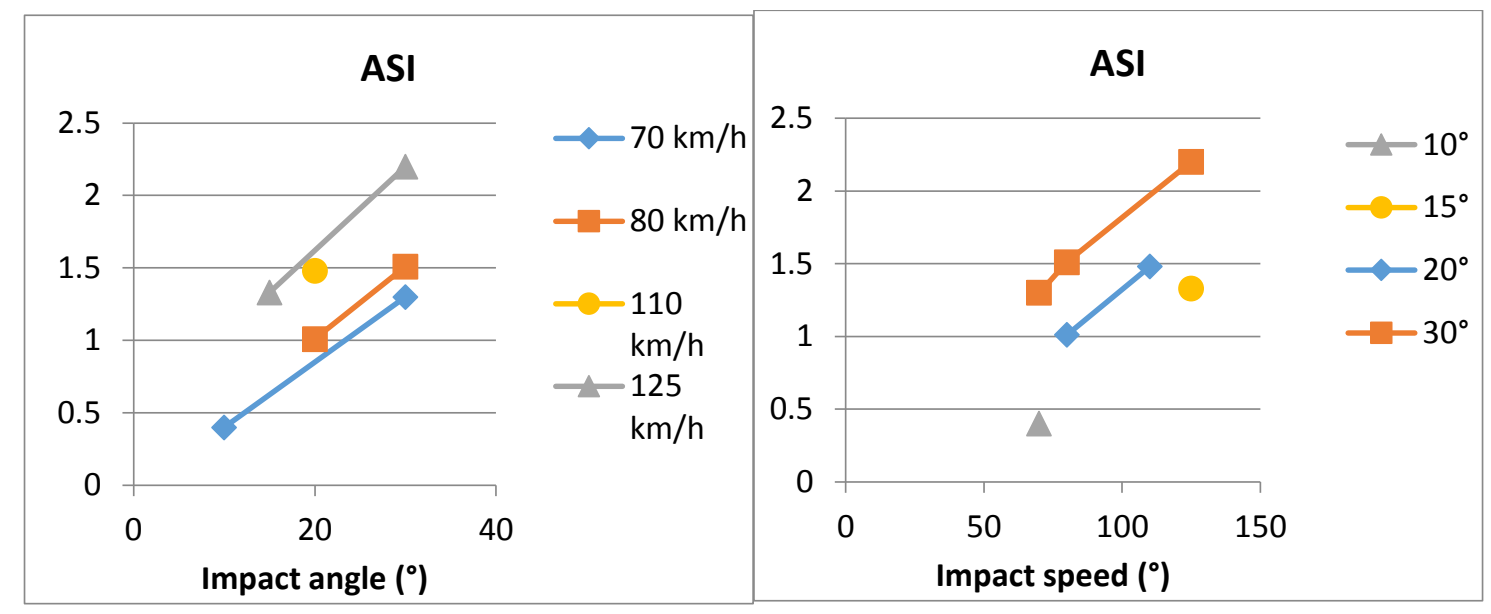

Figure 21: FE model predictions for (a) ASI vs impact angle; (b) ASI vs impact speed 


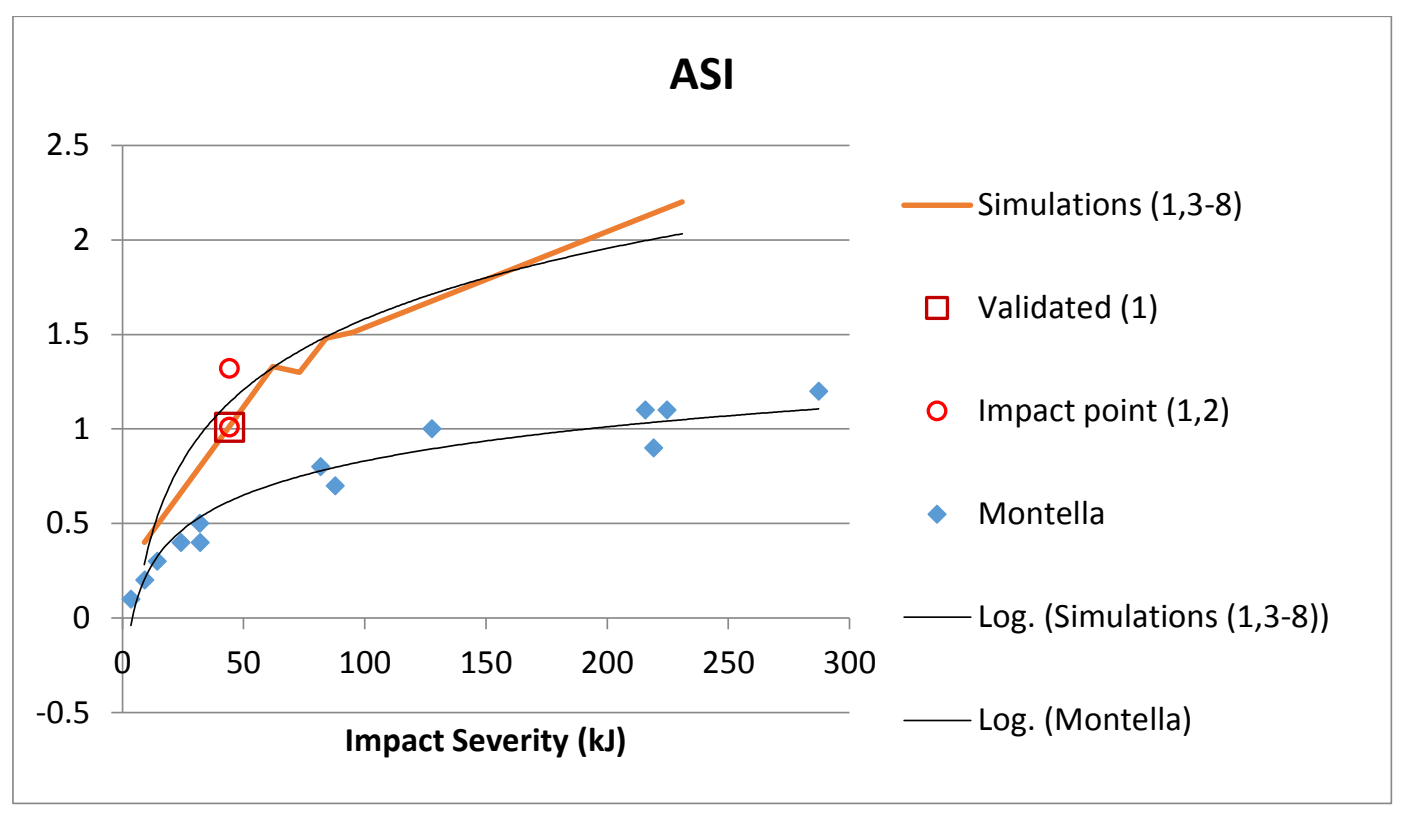

Figure 22: ASI vs Impact Severity (IS) of the FE simulations 